\title{
Evaluation of Some New Rice Genotypes under Irrigation Intervals at Different Two Locations
}

\author{
*M. I. M Salwau , S. A. S. Mehasen*, M. E. R. Gomma*, A. A. B. Abou khalifa** \\ and A. M. M. El-Sharawy ${ }^{* * *}$ \\ *Agron. Dept., Fac. of Agric., Benha Univ., Egypt. \\ *** RRTC, Field Crops Research Institute, ARC, Egypt. \\ *** kalubia Supply management
}

\begin{abstract}
Four field experiments were conducted at the Experiment and Research Center, Fac. Agric., Moshtohor, Benha Univ., Kalubia Governorate and Rice Research and Training Center, Sakha, Kafrelsheikh Governorate, Egypt in the two successive seasons 2011 and 2012 to study the performance of five new genotypes of rice under three irrigation intervals on yield and yield attributes. The most important results obtained from this study can be summarized as follows:

The highest values were recorded under irrigation intervals of 3 days, followed by irrigation every 6 days, however, the extra of the studied traits increasing irrigation intervals to 9 days significantly reduced the obtained characters values for all of the studied characters in both seasons under the two locations. Results showed that irrigation each 3 days allover the growing season gave reasonable production compared with irrigation every 6 and 9 days.

The GZ7576 genotype was of the earliest heading compared with the other rice genotypes in both seasons. While, Sakha106 genotype gave the highest values of root length, No. of panicles hill-1, No. of panicles m-2, panicle length, No. of grains panical-1, grain index and grain yield fed-1 in the both seasons at two locations.

Significant interaction effect for irrigation intervals and rice genotypes was obtained for No. of panicles $\mathrm{m}-2$ in the first season and heading date, No. of panicles hill-1, panicle length, No. of grains panical-1 and grain index in the second season at Moshtohor location. While, No. of panicles hill-1 in the both seasons and No. of panicles m-2and grain yield fed-1 in the first season were significantly affect by the interaction between irrigation intervals and rice genotypes at Kafrelshiekh location. Generally, irrigation every 3 days under Sakha 106 genotype treatment recorded the highest values for the studied traits in both seasons at two locations.
\end{abstract}

Keywords: Rice, Genotypes, Irrigation intervals, Yield and its components.

\section{Introduction}

Rice crop is a main crop among the different cultivated crops under Egyptian condition and all over the world. In Egypt, conventional irrigation method of rice consumes greater amounts of water, putting rice in the first demand among the grown summer crops, including sugar cane, maize and cotton. The highest water demand is more likely over to the highest water management of rice lines which was more than $6000 \mathrm{~m} 3$ fed-1, and the increased in its cultivated area which exceeded 2.0 million fed, during the last year few years. The total high water use by rice causes certain difficulties which negatively affect yields of summer thirsty crops. Egypt is completely depending on water from River Nile (55.5 Milliar m3, yearly). Rice alone consumes about $25 \%$ of such water. No doubt, the Government rightly intends to reduce rice growing areas by almost $50 \%$ of its current area, as a wise step to achieve better water management. The successful fit policy of water saving depends on some factors including lengthening irrigation interval, use of early rice cultivars.

Several researchers showed that increases the irrigations intervals, wherever, allowed the rice fields to dry for a few days in between irrigations intervals for 6 to 8 or 9 up to 12 days. Similar information reported by Mosalem et al, (1998), ElSharkawi et al, (2006), Okasha et al, (2009), Abu and Malgwi (2011) and Raumjit and Wichitparp (2014). The interval of 6 days gave reasonable production of rice grain and most of its components, as mentioned by El-Kalla et al, (2006), as well as El-Bably et al, (2007).

Several rice varieties of different ideal types are spreading all over the world. Thereafter, it could be expected that the rice varietal variation was detected in many studies such as Abou Khalifa, 2001, Khawshi et al, 2003, Abou El-Hassan et al, 2006, El-Kalla et al, 2006, El-Bably et al, 2007, Okasha et al, 2009, Abou Khalifa, 2012, Raumjit and Wichitparp, 2014.

The current study aims to investigate the effect of irrigation intervals on yield and its attributes of five newly rice genotypes at Moshtohor and Sakha locations.

\section{Materials and methods}

Four field experiments were conducted at the Experiment and Research Center, Fac. Agric., Moshtohor, Benha Univ., Kalubia Governorate and 
at Rice Research and Training Center Farm, Sakha, Kafrelsheikh Governorate, Egypt in the two successive seasons 2011 and 2012 to study the performance of new five genotypes of rice under three irrigation intervals on yield and yield attributes. Agricultural Practices: In both seasons, preceded crop was wheat. Seedbed of the nursery, area of 350 $\mathrm{m} 2$ for 1 fed was well prepared and fertilized with calcium super phosphate (15.5\% P2 O5) at $100 \mathrm{~kg}$ fed-1 before ploughing. Rice grains of the genotypes were soaked in running water for $48 \mathrm{hr}$., then incubated for another $48 \mathrm{hr}$. before seeding and $10 \mathrm{~kg}$ fed-1 of zinc sulphate was added. Seeds were manually broadcasted in the nursery on April 20th, at $60 \mathrm{~kg}$ fed-1 nursery. Two weeks after sowing, $40 \mathrm{~kg}$ $\mathrm{N}$ fed-1 was added at once as urea $(46 \% \mathrm{~N})$. Before transplanting, permanent field was well prepared, calcium super phosphate $(15.5 \%$ P2 O5) at rate 100 $\mathrm{kg}$ fed-1 was added to the dry soil before ploughing. Flushing irrigation was done. Nitrogen in the form of urea $(46 \% \mathrm{~N})$ at the rate $70 \mathrm{Kg} \mathrm{N}$ was added (according to the recommendation) three equal splits, $1 / 3$ as basal and incorporated in to dry soil immediately before flooding, $1 / 3$ was applied 30 days after transplanting, and $1 / 3$ was applied as top dressing 7 days before panicle initiation. Transplanting of seedlings from nursery to the permanent field was done 30 days after sowing, which transplanted in hills spaced $20 \times 20 \mathrm{~cm}$ for all rice genotypes, as three plants hill-1. Irrigation was withheld 15 days before harvest. Harvest was carried out according to each genotypes duration. All remainder agricultural practices were carried out as usual.

Experimental design: A split plot design with four replicates was used. The main plots were randomly devoted to irrigation intervals (3, 6 and 9 days), while rice genotypes were distributed at the sub plots. Randomization was considered in all cases. Plot area was $10.5 \mathrm{~m} 2(3 \times 3.5 \mathrm{~m})$.

\section{Studied attributes:}

After 55 days from sowing, samples were taken from the sub plot at random during the growing season to study days to $50 \%$ heading, number of days from sowing to $50 \%$ panicle emergence on the whole plot basis. At harvest, No. of panicles hill-1, No. of panicles $\mathrm{m}-2$, panicle length $(\mathrm{cm})$ and No. of grains panical-1 were measured. Grain yield ( $\mathrm{t}$ fed-1) was calculated on the base of yield plot- 1 then fed- 1 . Air dried plants were mechanically threshed and grain yield was estimated and adjusted to $14 \%$ moisture content. Grain samples from each sub plot were taken to determine 1000 grain weight.

\section{Statistical analysis}

Analysis of variance was done for the obtained data of each season separately according to Snedecor and Cochran (1980), the means and interaction compared according to the least significant difference (L.S.D) at 5\%.The data were analyzed statistically following sub plot design by MSTAT-C computer pakage developed by Russell (1986).

\section{Results and Discussion}

\section{-Irrigation intervals effect:}

Results in Table (1) showed that heading date, No. of panicles $\mathrm{m}-2$, panicle length, No. of grains panical-1, grain index and grain yield fed-1 were significantly affected by the irrigation intervals in both seasons at Moshtohor location. The highest values were recorded under continuous flooding irrigation interval of 3 days, followed by irrigation interval of 6 days, but no significant difference for No. of panicles $\mathrm{m}-2$ and grain index in both seasons and No. of grains panical-1 in the first season only. While, increasing irrigation intervals up to 9 days significantly reduced the values of all the studied attributes and grain yield fed-1 in the first and second seasons at Moshtohor location. Also, Kafrelshiekh location (Table 2), showed the same trend as was observed for irrigation each 3 days followed by irrigation each 6 days which recorded the highest values for all of the studied grain yield fed-1 and its attributes, but no significant difference for No. of panicles $\mathrm{m}-2$, No. of grains panical-1and grain index in the first season only. Irrigation interval of 3 and 6 days in the first season significantly increased No. of panicles $\mathrm{m}-2$, panicle length, No. of grains panical-1, grain index and grain yield fed-1 by 22.71 and 20.77, 15.75 and 11.44, 4.87 and 4.14, 13.94 and $9.89,14.10$ and $11.70 \%$, respectively compared with irrigation interval of 9 days. In the second season, the corresponding increases in rice root length, No. of panicles hill-1, No. of panicles $\mathrm{m}-2$, panicle length, No. of grains panical-1, grain index and grain yield fed-1were 23.26 and $18.88,13.92$ and $10.25,4.02$ and $3.18,18.18$ and $13.54,15.78$ and $13.23 \%$, respectively at Moshtohor location. At Kafrelshiekh location, the same trend was observed. This may be due to the decreas moisture content in root zone of rice plants for a long period, which adversely affected cell division, elongation and vegetative growth. These results revealed that the reduction in yield components can be expected as plants are exposed to water deficit. Besides, available water enhanced the production and transporting of dry matter content to the panicle resulting in more grain weight. These data are in agreement with those reported by Mosalem et al, (1998), El-Sharkawy et al, (2006), Okasha et al, (2009), Abu and Malgwi (2011) and Raumjit and Wichitparp (2014).

\section{-Genotypes Effect:}

Results reported in Table (1) clearly indicated that, there were significant differences between the different rice genotypes in all the of the studied traits in both seasons. The GZ7576 genotype was earliest 
heading compared with the other rice genotypes in both seasons at Moshtohor location. Sakha 106 genotype gave the highest values of No. of panicles m-2 wich were (652.08 and 680.83 panicle), panicle length $(23.25$ and $25.29 \mathrm{~cm})$, No. of grains panical1 (127.08 and 126.75 grain), grain index (24.92 and $25.00 \mathrm{~g})$ and grain yield fed-1(4.60 and 5.26 tons) in the subsquent first and second seasons, respectively. While, GZ7576 genotype gave the lowest values of No. of panicles m-2 (524.17 and 569.58 panicle), panicle length (18.58 and $19.29 \mathrm{~cm})$, No. of grains panicle-1 (119.08 and 119.25 grain), grain index (18.83 and $19.00 \mathrm{~g})$ and grain yield fed-1(3.50 and 4.22 tons) subsquent in the first and second seasons, respectively at Moshtohor location. At Kafrelshiekh location, Table (2) illustrated the similar trend. It could be concluded that genotypes differences among rice genotypes may be due to genetical make up. The superiority of Sakha 106 genotype in grain yield (kg fed-1) over the other the genotypes might be due to the increase in the growth and yield components, namely, root length, No. of panicles hill-1, No. of panicles m-2, panicle length, No. of grains panical-1 and grain index. (Abou Khalifa, (2001), Khawshi et al, (2003), Abou El-Hassan et al, (2006), El-Kalla et al, (2006),El-Bably et al, (2007), Okasha et al, (2009), Abou Khalifa, (2012), Raumjit and Wichitparp, (2014) calcified marked differences among rice varieties and genotypes in yield and yield components of rice.

Table 1. Yield and its attributes of rice as affected by irrigation intervals and genotypes in 2011 and 2012 seasons at Moshtohor Location

\begin{tabular}{|c|c|c|c|c|c|c|}
\hline Treatments & $\begin{array}{l}\text { Heading date } \\
\text { (day) }\end{array}$ & $\begin{array}{c}\text { No. of } \\
\text { Panicles } \mathrm{m}-2\end{array}$ & $\begin{array}{c}\text { Panicle } \\
\text { length } \\
(\mathrm{cm})\end{array}$ & $\begin{array}{c}\text { No. of grains } \\
\text { panical-1 }\end{array}$ & $\begin{array}{l}\text { Grain index } \\
(\mathrm{g})\end{array}$ & $\begin{array}{l}\text { Grain yield } \\
(\mathrm{t} \text { fed-1) }\end{array}$ \\
\hline Intervals & \multicolumn{6}{|c|}{2011 season } \\
\hline 3 days & 105.40 & 633.50 & 22.05 & 125.43 & 23.05 & 4.29 \\
\hline 6 days & 103.05 & 623.50 & 21.23 & 124.55 & 22.23 & 4.20 \\
\hline 9 days & 102.10 & 516.25 & 19.05 & 119.60 & 20.23 & 3.76 \\
\hline LSD at $5 \%$ & 0.78 & 36.42 & 0.52 & 2.23 & 1.14 & 0.03 \\
\hline \multicolumn{7}{|l|}{ Genotypes } \\
\hline Sakha106 & 105.58 & 652.08 & 23.25 & 127.08 & 24.92 & 4.60 \\
\hline Sakha105 & 104.92 & 628.33 & 22.13 & 124.92 & 23.88 & 4.44 \\
\hline GZ9362 & 103.75 & 588.33 & 20.50 & 123.54 & 22.04 & 4.07 \\
\hline GZ9057 & 102.25 & 562.50 & 19.42 & 121.33 & 19.50 & 3.79 \\
\hline GZ7576 & 101.08 & 524.17 & 18.58 & 119.08 & 18.83 & 3.50 \\
\hline LSD at $5 \%$ & 1.04 & 12.67 & 0.79 & 0.79 & 0.76 & 0.13 \\
\hline IxG & NS & $*$ & NS & NS & NS & NS \\
\hline Intervals & \multicolumn{6}{|c|}{2012 season } \\
\hline 3 days & 105.95 & 682.25 & 23.33 & 125.45 & 23.40 & 4.99 \\
\hline 6 days & 103.85 & 658.00 & 22.58 & 124.43 & 22.48 & 4.88 \\
\hline 9 days & 102.60 & 553.50 & 20.48 & 120.60 & 19.80 & 4.305 \\
\hline LSD at $5 \%$ & 1.02 & 27.18 & 0.67 & 0.66 & 1.06 & 0.21 \\
\hline \multicolumn{7}{|l|}{ Genotypes } \\
\hline Sakha106 & 108.00 & 680.83 & 25.29 & 126.75 & 25.00 & 5.26 \\
\hline Sakha105 & 105.50 & 659.17 & 23.63 & 125.58 & 23.54 & 5.01 \\
\hline GZ9362 & 103.67 & 640.83 & 22.13 & 124.04 & 21.92 & 4.70 \\
\hline GZ9057 & 102.25 & 605.83 & 20.29 & 121.83 & 20.00 & 4.43 \\
\hline GZ7576 & 101.25 & 569.58 & 19.29 & 119.25 & 19.00 & 4.22 \\
\hline LSD at $5 \%$ & 0.67 & 17.76 & 0.59 & 0.69 & 0.51 & 0.14 \\
\hline IxG & $*$ & NS & $*$ & $* *$ & $*$ & NS \\
\hline
\end{tabular}


Table 2. Yield and its attributes of rice as affected by irrigation intervals and genotypes in 2011 and 2012 seasons at Kafrelshaikh Location

\begin{tabular}{|c|c|c|c|c|c|c|}
\hline Treatments & $\begin{array}{l}\text { Heading date } \\
\text { (day) }\end{array}$ & $\begin{array}{c}\text { No. of } \\
\text { panicles m- } \\
2 \\
\end{array}$ & $\begin{array}{c}\text { Panicle } \\
\text { length } \\
(\mathrm{cm})\end{array}$ & $\begin{array}{l}\text { No. of grains } \\
\text { panical-1 }\end{array}$ & $\begin{array}{c}\text { Grain } \\
\text { index } \\
(\mathrm{g}) \\
\end{array}$ & $\begin{array}{c}\text { Grain yield } \\
(\text { kg fed-1) }\end{array}$ \\
\hline Intervals & \multicolumn{6}{|c|}{2011 season } \\
\hline 3 days & 105.55 & 637.50 & 22.13 & 120.90 & 25.45 & 4.29 \\
\hline 6 days & 102.60 & 612.50 & 20.56 & 119.50 & 24.45 & 4.13 \\
\hline 9 days & 101.40 & 475.00 & 19.49 & 114.05 & 23.01 & 3.60 \\
\hline LSD at $5 \%$ & 1.02 & 32.24 & 1.06 & 4.47 & 1.51 & 0.11 \\
\hline \multicolumn{7}{|l|}{ Genotypes } \\
\hline Sakha106 & 104.92 & 639.58 & 21.92 & 122.17 & 26.89 & 4.53 \\
\hline Sakha105 & 103.42 & 606.25 & 21.31 & 120.33 & 25.29 & 4.17 \\
\hline GZ9362 & 103.42 & 579.17 & 20.49 & 117.67 & 23.86 & 3.98 \\
\hline GZ9057 & 102.25 & 545.83 & 20.58 & 115.25 & 22.90 & 3.79 \\
\hline GZ7576 & 101.92 & 504.17 & 19.32 & 115.33 & 22.58 & 3.57 \\
\hline LSD at $5 \%$ & 1.94 & 24.72 & 1.01 & 4.72 & 1.56 & 0.14 \\
\hline IxG & NS & $*$ & $\mathrm{NS}$ & NS & NS & $* *$ \\
\hline Intervals & \multicolumn{6}{|c|}{2012 season } \\
\hline 3 days & 106.55 & 656.25 & 22.99 & 124.60 & 25.95 & 4.44 \\
\hline 6 days & 104.05 & 612.50 & 21.34 & 120.70 & 24.86 & 4.24 \\
\hline 9 days & 102.55 & 496.25 & 19.92 & 115.70 & 24.06 & 3.41 \\
\hline LSD at $5 \%$ & 0.43 & 26.07 & 0.67 & 1.97 & 0.66 & 0.09 \\
\hline \multicolumn{7}{|l|}{ Genotypes } \\
\hline Sakha106 & 106.42 & 672.92 & 22.80 & 124.58 & 27.78 & 4.64 \\
\hline Sakha105 & 104.83 & 614.58 & 22.40 & 123.08 & 25.93 & 4.21 \\
\hline GZ9362 & 104.42 & 587.50 & 21.39 & 120.67 & 24.60 & 3.91 \\
\hline GZ9057 & 103.58 & 556.25 & 20.72 & 118.58 & 23.68 & 3.79 \\
\hline GZ7576 & 102.67 & 510.42 & 19.75 & 114.75 & 22.79 & 3.56 \\
\hline LSD at $5 \%$ & 0.99 & 25.15 & 0.67 & 1.88 & 0.81 & 0.15 \\
\hline $\mathrm{IxG}$ & NS & $\mathrm{NS}$ & NS & NS & $\mathrm{NS}$ & NS \\
\hline
\end{tabular}

\section{-Interaction effect:}

The effect of the interaction showed significant or highly significant effect for No. of panicles $\mathrm{m}-2$ in the first season and heading date, panicle length, No. of grains panical-1 and grain index in the second season at Moshtohor location, but the other traits didn't show any significant effects in the both seasons (Table1). Concerning the interaction between irrigation intervals and rice genotypes, results in Table (3) indicated that continuous flooding (3 days) under Sakha106 genotype treatment recorded the highest values of No. of panicles $\mathrm{m}-2$ (706.25 and 750.00 panicle), panicle length $(25.25$ and $26.50 \mathrm{~cm})$, No. of grains panical1(129.50 and 128.75 grain) and grain index (26.50 and $27.00 \mathrm{~g}$ ) in the first and second seasons respectively. While, irrigation interval 9 days under GZ7576 genotype was of earlier heading (100.25 and 100.75 day) in the first and second seasons respectively. On the other hand, irrigation every 9 days under GZ7576 genotype treatment gave the lowest values of No. of panicles m-2 (462.5 and 500.0 panicle), panicle length $(17.75$ and $18.63 \mathrm{~cm})$,
No. of grains panical-1(115.75 and 117.00 grain) and grain index (17.75 and $17.25 \mathrm{~g}$ ) in the first and second seasons respectively at Moshtohor location.

The of the interaction showed significant effect or highly significant for No. of panicles m-2 and grain yield fed-1 in the first season at Kafrelshiekh location, but the other traits didn't show any significant effects in the both seasons Table (2). The interaction between irrigation intervals and rice genotypes, (Table 4) indicated that continuous flooding (3 days) under Sakha106 genotype treatment recorded the highest values of No. of panicles $\mathrm{m}-2$ (700.00 and 737.50 panicle) and grain yield fed-1 (4.88 and 4.95 t) in the first and second seasons respectively. On the other hand, irrigation interval 9 days under GZ7576 genotype treatment gave the lowest values of No. of panicles $\mathrm{m}-2$ (443.75 and 443.75 panicle) and grain yield fed-1 (3.28 and $3.03 \mathrm{t}$ ) in the first and second seasons respectively at Kafrelshiekh location. 
Table 3. Effect the interaction between irrigation intervals and genotypes on some attributes of rice in 2011 and 2012 seasons at Moshtohor Location

\begin{tabular}{|c|c|c|c|c|c|c|}
\hline \multirow{3}{*}{ Treatments } & \multicolumn{3}{|c|}{ (First season) } & \multicolumn{3}{|c|}{ (Second season) } \\
\hline & \multicolumn{3}{|c|}{ Irrigation intervals } & \multicolumn{3}{|c|}{ Irrigation intervals } \\
\hline & 3 days & 6 days & 9 days & 3 days & 6 days & 9 days \\
\hline Genotypes & \multicolumn{6}{|c|}{ Heading date (day) } \\
\hline Sakha106 & 108.75 & 104.50 & 103.50 & 110.00 & 108.00 & 106.00 \\
\hline Sakha105 & 107.25 & 105.00 & 102.50 & 107.75 & 105.25 & 103.50 \\
\hline GZ9362 & 105.25 & 103.25 & 102.75 & 105.75 & 103.50 & 101.75 \\
\hline GZ9057 & 103.50 & 101.75 & 101.50 & 104.25 & 101.50 & 101.00 \\
\hline GZ7576 & 102.25 & 100.75 & 100.25 & 102.00 & 101.00 & 100.75 \\
\hline L.S.D at $5 \%$ & \multicolumn{3}{|c|}{ NS } & \multicolumn{3}{|c|}{1.16} \\
\hline Genotypes & \multicolumn{6}{|c|}{ No. of panicles $\mathrm{m}-2$} \\
\hline Sakha106 & 706.25 & 668.75 & 581.25 & 750.00 & 688.75 & 603.75 \\
\hline Sakha105 & 675.00 & 672.50 & 537.50 & 718.75 & 676.25 & 582.50 \\
\hline GZ9362 & 625.00 & 627.50 & 512.50 & 686.25 & 686.25 & 550.00 \\
\hline GZ9057 & 598.75 & 601.25 & 487.50 & 650.00 & 636.25 & 531.25 \\
\hline GZ7576 & 562.50 & 547.50 & 462.50 & 606.25 & 602.50 & 500.00 \\
\hline L.S.D at $5 \%$ & \multicolumn{3}{|c|}{21.94} & \multicolumn{3}{|c|}{$\mathrm{NS}$} \\
\hline Genotypes & \multicolumn{6}{|c|}{ Panicle length $(\mathrm{cm})$} \\
\hline Sakha106 & 25.25 & 23.75 & 20.75 & 26.50 & 25.88 & 23.50 \\
\hline Sakha105 & 23.75 & 22.63 & 20.00 & 25.00 & 24.38 & 21.50 \\
\hline GZ9362 & 21.50 & 21.25 & 18.75 & 23.63 & 22.75 & 20.00 \\
\hline GZ9057 & 20.50 & 19.75 & 18.00 & 21.50 & 20.38 & 19.00 \\
\hline GZ7576 & 19.25 & 18.75 & 17.75 & 20.00 & 19.50 & 18.63 \\
\hline L.S.D at $5 \%$ & \multicolumn{3}{|c|}{ NS } & \multicolumn{3}{|c|}{1.03} \\
\hline Genotypes & \multicolumn{6}{|c|}{ No. of grains panical-1 } \\
\hline Sakha106 & 129.50 & 128.25 & 123.50 & 128.75 & 127.00 & 124.50 \\
\hline Sakha105 & 127.50 & 126.25 & 121.00 & 128.00 & 126.75 & 122.00 \\
\hline GZ9362 & 125.62 & 125.00 & 120.00 & 125.75 & 125.88 & 120.50 \\
\hline GZ9057 & 123.75 & 122.50 & 117.75 & 123.75 & 122.75 & 119.00 \\
\hline GZ7576 & 120.75 & 120.75 & 115.75 & 121.00 & 119.75 & 117.00 \\
\hline L.S.D at $5 \%$ & \multicolumn{3}{|c|}{ NS } & \multicolumn{3}{|c|}{0.99} \\
\hline Genotypes & \multicolumn{6}{|c|}{ Grain index $(\mathrm{g})$} \\
\hline Sakha106 & 26.50 & 25.25 & 23.00 & 27.00 & 25.50 & 22.50 \\
\hline Sakha105 & 25.00 & 24.63 & 22.00 & 25.50 & 24.25 & 20.88 \\
\hline GZ9362 & 23.25 & 22.63 & 20.25 & 23.25 & 22.63 & 19.88 \\
\hline GZ9057 & 20.75 & 19.62 & 18.13 & 21.00 & 20.50 & 18.50 \\
\hline GZ7576 & 19.75 & 19.00 & 17.75 & 20.25 & 19.50 & 17.25 \\
\hline L.S.D at $5 \%$ & \multicolumn{3}{|c|}{ NS } & \multicolumn{3}{|c|}{0.88} \\
\hline
\end{tabular}

Table 4. The interaction effect the interval of between irrigation intervals and genotypes on some attributes of rice in 2011 and 2012 seasons at Kafrelshaikh Location

\begin{tabular}{|c|c|c|c|c|c|c|}
\hline \multirow{3}{*}{ Treatments } & \multicolumn{3}{|c|}{ First season } & \multicolumn{3}{|c|}{ Second season } \\
\hline & \multicolumn{3}{|c|}{ Irrigation intervals } & \multicolumn{3}{|c|}{ Irrigation intervals } \\
\hline & 3 days & 6 days & 9 days & 3 days & 6 days & 9 days \\
\hline Genotypes & \multicolumn{6}{|c|}{ No. of panicles $\mathrm{m}-2$} \\
\hline Sakha106 & 700.00 & 700.00 & 518.75 & 737.50 & 700.00 & 581.25 \\
\hline Sakha105 & 681.25 & 650.00 & 487.50 & 681.25 & 650.00 & 512.50 \\
\hline GZ9362 & 643.75 & 618.75 & 475.00 & 662.50 & 618.75 & 481.25 \\
\hline GZ9057 & 612.50 & 575.00 & 450.00 & 631.25 & 575.00 & 462.50 \\
\hline GZ7576 & 550.00 & 518.75 & 443.75 & 568.75 & 518.75 & 443.75 \\
\hline L.S.D at $5 \%$ & \multicolumn{3}{|c|}{42.82} & \multicolumn{3}{|c|}{$\mathrm{NS}$} \\
\hline Genotypes & \multicolumn{6}{|c|}{ Grain yield (kg fed-1) } \\
\hline Sakha106 & 4.88 & 4.75 & $3.95^{\circ}$ & 4.95 & 4.88 & 4.10 \\
\hline Sakha105 & 4.60 & 4.33 & 3.58 & 4.70 & 4.50 & 3.43 \\
\hline GZ9362 & 4.15 & 4.03 & 3.75 & 4.33 & 4.08 & 3.33 \\
\hline GZ9057 & 4.00 & 3.95 & 3.43 & 4.20 & 4.03 & 3.15 \\
\hline GZ7576 & 3.83 & 3.60 & 3.28 & 3.95 & 3.70 & 3.03 \\
\hline L.S.D at $5 \%$ & \multicolumn{3}{|c|}{0.24} & \multicolumn{3}{|c|}{$\mathrm{NS}$} \\
\hline
\end{tabular}




\section{Reference}

Abou El-Hassan, W.H , Y. Kitamura, K. Hasegawa, S. L. Yang and H. Solomon, 2006. Water management using drainage water and its impact on irrigated rice in the Delta Region of Egypt. Eighth International Conference on Dryland Development, 25-28 February 2006, Beijing, China.

Abou Khalifa, A. A. 2012. Response of some rice varieties to different sowing dates. Proc. 13th international Conf. Agron.,Fac.of Agric., Benha Univ., Egypt, 9-10 September,pp:94-102

Abou Khalifa, A.A., 2001. Response of some rice varieties to nitrogen fertilizer application under different irrigation intervals. Ph.D. Thesis Department of Agronomy \& Agricultural Mechanization Faculty of agriculture, Moshtohor, Zagazig University, Banha Branch.

Abu, S.T. and W. B. Malgwi, 2011. Effects of deficit irrigation regime and interval on chemical properties and paddy rice yield in sudan savanna of nigeria. Journal of Agronomy, 10: 48-55.

El-Bably, A. Z, A. A. A. Allah and M. I. Meleha, 2007. Influence of field submergence depths on rice productivity in North Delta, Egypt. Alexandria Journal of Agricultural Research, 52(2): 29-35.

El-Kalla, S. E., A. M. El-Said, A.A.M. Abd ElRahman and A. M. S. Kishk, 2006. Response of rice cultivars to irrigation intervals and some organic fertilizer treatments in newly reclaimed soils. Agric. Sci., Mansoura Univ., 31(9): 55475555 .
EL-Sharkawi, H. M, B. Zayed, T. Honna and S. Yamamoto, 2006. Chemical Compositions and Salinity Development in Paddy Soil as Affected by Irrigation Intervals of Mixed Water under Saline Soil. Pakistan Journal of Biological Sciences, 9(4):741-745.

Khawshi, D.G, N.G. Zode, S. L. Borkar and U.R. Dongarwar, 2003. Response of scented varieties of paddy (Oryza sativa L) to spacing in Eastern Vidarbha Zone of Maharashtra. Annals of Plant Physiology, 17(1): 81-83.

Mosalem, M. E, F.N. Mahrous, I.S. El-Refaee and F.A. Sorour, 1998. Effect of irrigation interval and potassium fertilization level on growth, yield and quality of rice. Annals of Agricultural Science, Cairo, (Special issue): 663-678.

Okasha E. M, M. A. A. Abdou, A. A. El-Ganayni and W.M. EL-Khoby, 2009. Influence of irrigation intervals, some cultivars and plant spacing on growth, yield and its components in rice part (2) yield and yield components. Res. J. Agric. \& Biol. Sci., 5(5): 828-839

Raumjit N. and T. Wichitparp, 2014. Effect of drought condition on growth, yield and grain quality of upland rice. American Journal of Agricultural and Biological Sciences, 9 (3): 439444

Russell, D. F. 1986. MSTAT-C. Computer based data analysis software crop and soil Sci, Dept., Michigan, State Univ., USA.

Snedecor, G. W. and W. G. Cochran, 1980. Statistical Methods, 7th Ed., Iowa State Univ. Press, Ames, Iowa, USA.

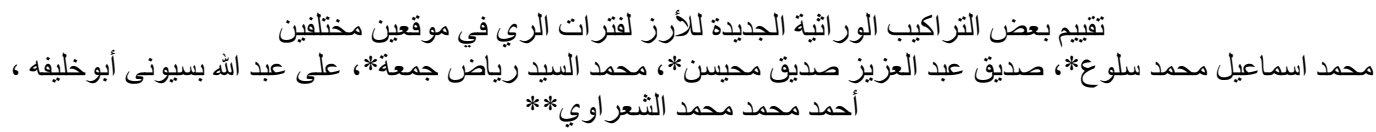

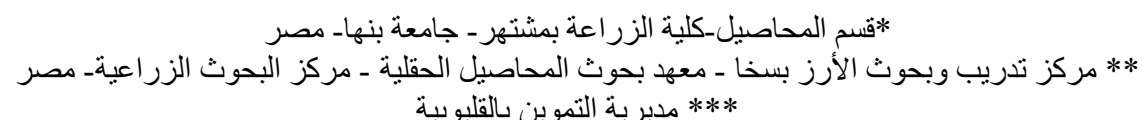

أجريت أربع تجارب حقلية ، اثثتان بمركز البحوث و التجارب الزر اعية بكلية زر اعة مشتهر -جامعة بنها ـمحافظة القليوبية ، و واثتتان

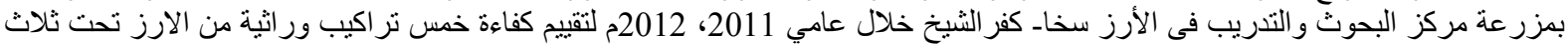

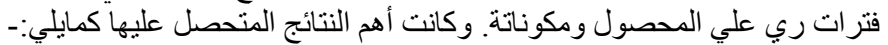

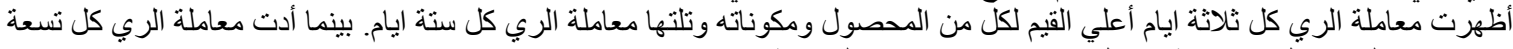

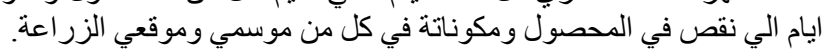

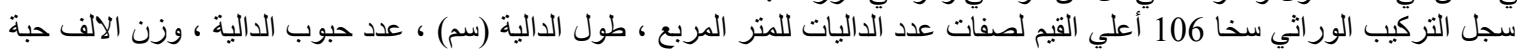

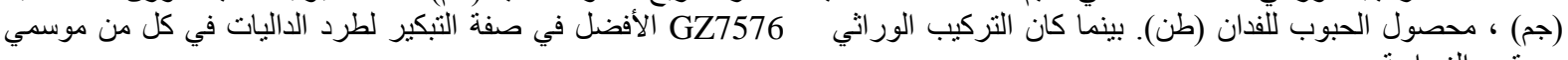

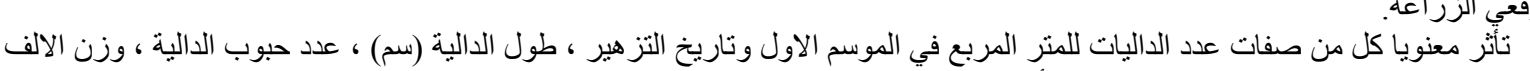

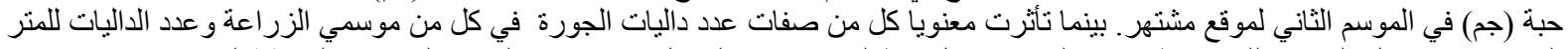

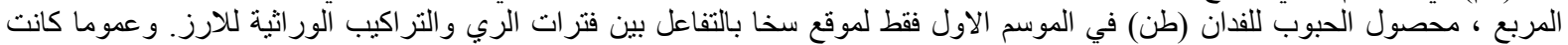

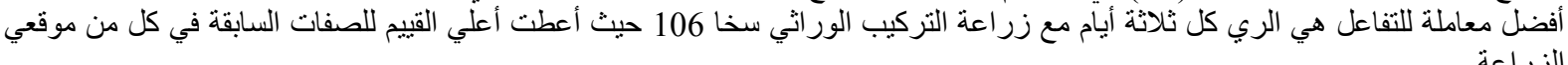

